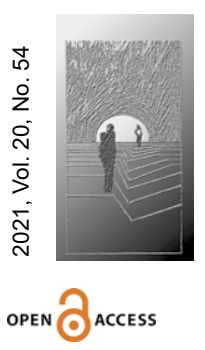

\title{
Prawo dziecka do relacji osobistej z rodzicami w sytuacji ich rozstania
}

\section{STRESZCZENIE}

CEL NAUKOWY: Celem opracowania jest analiza sytuacji dziecka w relacji osobistej z rodzicem w czasie kryzysu w rodzinie, jakim jest rozstanie rodziców, uwzględniając obowiązujące przepisy prawa polskiego.

PROBLEM I METODY BADAWCZE: Problemem do rozwiązania stała się odpowiedź na pytanie, czy obowiązujące przepisy w sposób właściwy określają prawo do relacji osobistych dziecka z rodzicami żyjącymi w rozłączeniu. W zakresie przyjętej metodologii zastosowano założenia filozofii antropologicznej, filozofii personalistycznej, filozofii dialogu, praw człowieka i filozofii odpowiedzialności, a także metodę dogmatyczno-prawną oraz metodę analizy i krytyki piśmiennictwa.

PROCES WYWODU: Opracowanie rozpoczyna zwrócenie uwagi na problem relacji osobistej dziecka z rodzicami po ich rozstaniu. Następnie dokonano analizy art. $113 \S 1$ Kodeksu rodzinnego i opiekuńczego w kontekście prawidłowości ujmowania relacji z rodzicem jako obowiązku dziecka, a także prawidłowości ograniczenia regulacji sfery stosunków z rodzicami po ich rozstaniu do kontaktów. Wskazano także na sposób, w jaki regulacje międzynarodowe określają relacje dziecka z rodzicami żyjącymi w separacji.

WYNIKI ANALIZY NAUKOWEJ: Podjęte badania wskazują na konieczność dostosowania polskich regulacji do standardów międzynarodowych i pełniejsze uwzględnienie podmiotowości i godności osobowej dziecka.

WNIOSKI, INNOWACJE, REKOMENDACJE: Postuluje się zmianę regulacji art. 113 § 1 Kodeksu rodzinnego i opiekuńczego poprzez usunięcie kategorii obowiązku dziecka do kontaktu z rodzicem oraz zmianę pojęcia kontakt na szerszą definicję osobistych relacji.

$\rightarrow$ SŁOWA KLUCZE: PRAWA DZIECKA, RELACJA OSOBISTA DZIECKA I RODZICA, ODPOWIEDZIALNOŚĆ RODZICIELSKA, RODZICE ŻYJĄCY W ROZŁĄCZENIU 


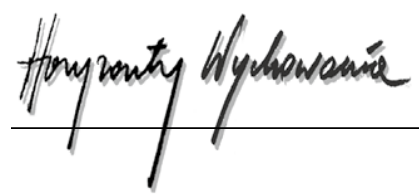

ABSTRACT

The child's right to a personal relationship with separated parents

RESEARCH OBJECTIVE: The aim of the study is to analyze the situation of the child in the personal relationship with a parent during the crisis in the family, which is the separation of the parents, taking into account Polish law.

THE RESEARCH PROBLEM AND METHODS: The research problem forms of a question: do the current regulations properly define the right to the personal relationships between a child and separated parents? The methodology is concerned, systematical analyze has been applied with elements of anthropological philosophy, personalistic philosophy, philosophy of dialogue, human rights and philosophy of responsibility.

THE PROCESS OF ARGUMENTATION: The study begins with drawing an attention to the problem of the child's personal relationship with separated parents. Then Art. $113 \S 1$ of the Family and Guardianship Code has been analyzed in the context of the correctness of treating the relationship with the parent as a child's duty, as well as the correctness of limiting the regulation of the sphere of relations with separated parents to contacts. It also indicated the way in which international regulations define the child's relationship with separated parents.

RESEARCH RESULTS: The analyze has led to a conclusion, that it is the necessity to adjust Polish regulations to international standards and to take fuller account of the subjectivity and personal dignity of the child more fully.

CONCLUSIONS, INNOVATIONS, AND RECOMMENDATIONS: It is postulated to change the regulation of Art. $113 \S 1$ of the Family and Guardianship Code by removing the category of the child's duty to contact the parent and changing the concept of contact to a broader definition of personal relationships.

\section{$\rightarrow$ KEYWORDS: CHILDREN'S RIGHTS, PERSONAL RELATIONSHIP BETWEEN A CHILD AND A PARENT, PARENTAL RESPONSIBILITY, SEPARATED PARENTS}

\section{Wstęp}

Rodzina jest podstawową komórką społeczną i naturalnym środowiskiem opiekuńczo-wychowawczym dla dziecka. Stanowi małą grupę społeczną, dlatego też występują w niej bezpośrednie relacje między członkami rodziny, bliskie stosunki nasycone emocjami (Plopa, 2008). Wychowanie w rodzinie stanowi „pierwszą szkołę wychowania dla ogromnej większości ludzi” (Okoń, 1996, s. 323). To członkowie rodziny dostarczają modeli osobowych i wzorców zachowań w różnych sytuacjach - zarówno typowych dla dnia codziennego, jak i w trakcie wydarzeń szczególnych, wyjątkowych dla rodziny. 
Niezwykle istotne dla rozwoju dziecka są jego relacje z rodzicami, dlatego też rozpad rodziny stanowi w każdym przypadku bardzo trudną sytuację dla dziecka i jest potencjalnym zagrożeniem dla jego dobra.

\section{Metody badawcze}

Przedmiotem badań naukowych jest analiza sytuacji dziecka w relacji osobistej z rodzicem w czasie kryzysu w rodzinie, jakim jest rozstanie rodziców w kontekście obowiązujących przepisów prawa. Przyjętym problemem do rozwiązania stała się odpowiedź na pytanie, czy obecnie obowiązujące przepisy w sposób właściwy określają prawo do relacji osobistych dziecka z rodzicami żyjącymi w rozłączeniu. Szczegółowe problemy badawcze sprowadzają się do odpowiedzi na pytania: czy utrzymywanie relacji z rodzicem po rozpadzie rodziny może być ujmowane w kategorii obowiązku dziecka? Czy ustalenie w przepisach powszechnie obowiązującego prawa i obowiązku dziecka do kontaktu z rodzicem jest wystarczającą regulacją odnoszącą się do jego relacji z rodzicami po rozstaniu? I wreszcie: w jaki sposób regulacje międzynarodowe określają sytuację dziecka, którego rodzice żyją w separacji w kontekście utrzymywania relacji z rodzicami i czy polskie przepisy odpowiadają normom uniwersalnym i regionalnym?

Do rozwiązania problemu badawczego zastosowano metodę dogmatyczno-prawną, analizy i krytyki piśmiennictwa (źródeł), a także analizę i syntezę, uogólnianie i wnioskowanie jako oparcie w procesach poznania myślowego.

\section{Utrzymywanie relacji z rodzicem - prawo czy obowiązek dziecka?}

W art. 72 ust. 1 Konstytucji RP z dnia 2 kwietnia 1997 r. (Dz.U. 1997, Nr 78, poz. 483 ze zm.), podkreślono, że RP zapewnia ochronę praw dziecka. Z normy tej wywodzi się doniosłą wartość, jaką jest dobro dziecka. „Dobro dziecka” stanowi ,jądro wszystkich przepisów o prawach dziecka. Jest instrumentem wykładni norm obowiązujących, jak i dyrektywą w przypadku tworzenia prawa i jego stosowania, kryterium oceny przy podejmowaniu decyzji w sprawach dziecka oraz rozstrzyganiu kolizji interesów dziecka i innych osób zwłaszcza rodziców" (Stojanowska, 2000, s. 32). Dobro dziecka ujmowane jest jako: „stan, w którym dziecko osiąga prawidłowy, całościowy i harmonijny rozwój psychiczny, fizyczny i społeczny, z poszanowaniem jego godności i wynikających z niej naturalnych praw. Dobro to jest kształtowane w szczególności przez pozytywne relacje osobiste, relacje rodzinne i sytuacje wychowawcze" (Kodeks rodzinny. Projekt, 2019, s. 427).

W zmieniających się przepisach prawa rodzinnego nie zawsze paradygmat „dobra dziecka" pozostaje wiodący. W nowelizacji art. 113 § 1 Ustawy z dnia 25 lutego 1964 r. Kodeks rodzinny i opiekuńczy (t.j. Dz.U. z 2020, poz. 1359 ze zm. - dalej jako k.r.io.), która miała miejsce w 2008 r., stwierdzono, że „rodzice oraz ich dzieci mają prawo i obowiązek utrzymywania ze sobą kontaktów". Jak wskazuje S.L. Stadniczeńko, znowelizowana 


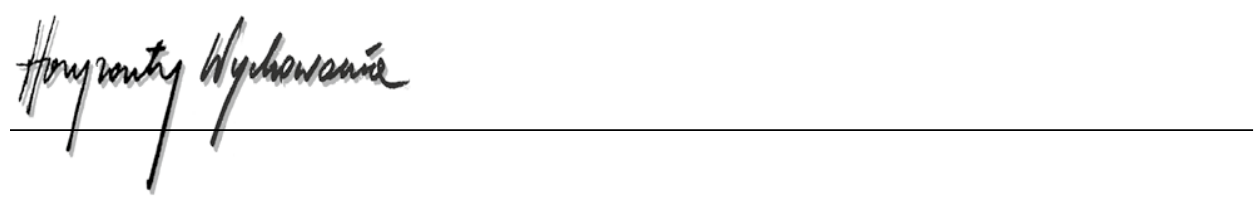

treść stanowi zaprzeczenie dobra dziecka, gdyż wzmacnia postawy rodzicielskie oparte na legalizmie i formalizmie, związane ze sztywnym respektowaniem rozstrzygnięć sądu w zakresie kontaktowania się z dzieckiem, bez uwzględnienia potrzeb czy odczuć dziecka (Stadniczeńko, 2015, s. 89). Egzekwowanie przez rodzica żyjącego w rozłączeniu prawa do kontaktów z dzieckiem wbrew woli małoletniego i zasłanianie się jego obowiązkiem w tym zakresie, stanowi uprzedmiotowienie dziecka. Na niebezpieczeństwo wykorzystywania normy art. $113 \S 1$ k.r.io. dla realizacji interesu rodziców pragnących kontaktów z dzieckiem nawet za cenę stosowania przymusu wobec małoletniego, wskazują także inni przedstawiciele doktryny (Stojanowska, 2011, s. 265 i n.; Hendrych, 2016, s. 95; Długoszewska, 2012, s. 90 i n.; Ignaszewski, 2011, s. 26). W doktrynie występują także głosy wskazujące na pozytywny aspekt wprowadzenia obowiązku dziecka do kontaktu z rodzicem, co miało na celu wzmocnienie pozycji rodzica żyjącego w rozłączeniu (Justyński, 2011, s. 134), czy też stanowi naturalną konsekwencję prawa rodzica (Sokołowski, 2013). Spotkać można również stanowisko wyjaśniające istotę obowiązku dziecka do kontaktu z rodzicem swoistą „relacją zmienną” („obrotową”) prawa i obowiązku rodziców i dziecka (więcej: Zajączkowska, 2018, s. 283).

Koncepcja obowiązku dziecka do kontaktu z rodzicem nie wytrzymuje konfrontacji z treścią art. 1131 § 1 k.r.io., w którym wskazano, że sposób utrzymywania kontaktów ma zostać ustalony z uwzględnieniem rozsądnych życzeń dziecka. Mamy zatem do czynienia z możliwością rozsądnego wyboru obowiązku, co stanowi konstrukcję nielogiczną. Przepis art. $1131 \S 1$ jest skorelowany z art. $95 \S 4$ k.r.io., w którym nałożono na rodziców obowiązek wysłuchania dziecka w ważnych sprawach dotyczących jego osoby lub majątku. Obowiązek wysłuchania dziecka jest aktualny także w trakcie sporu sądowego co do sposobu i zakresu kontaktów - w treści art. 2161 oraz 576 § 2 ustawy z dnia 17 listopada 1964 r. Kodeks postępowania cywilnego (t.j. Dz.U. 2020, poz. 1575 ze zm.) został nałożony na sąd obowiązek wysłuchania dziecka poza salą posiedzeń, jeżeli jego rozwój umysłowy, stan zdrowia i stopień dojrzałości na to pozwala, oraz uwzględnienia jego zdania i rozsądnego życzenia. Jak wskazuje H. Ciepła: „Nie leży w interesie dziecka zmuszanie go do kontaktów z rodzicami, jeżeli wielokrotnie odmawia na nie zgody, nawet po psychologicznym przygotowaniu zarówno jego, jak i rodziców" (2010, s. 71).

Celem wysłuchania dziecka jest przekonanie sądu o potrzebie wydania określonego rozstrzygnięcia, przy uwzględnieniu rozsądnych życzeń małoletniego (Haak, 2017, s. 404). Moim zdaniem sąd może nie uwzględnić zdania dziecka, tylko jeśli ma wątpliwości co do samodzielności i racjonalności życzenia z uwagi np. na stopień dojrzałości dziecka czy wpływ drugiego z rodziców

Przychylam się do poglądu o braku słuszności nakładania na dziecko obowiązku kontaktu z rodzicem, którego przymusowa egzekucja może przynieść skutek pogorszenia relacji z rodzicem. W przypadku niechęci dziecka do spotkań z rodzicem należałoby raczej rozpocząć pracę psychologiczną z całą rodziną, niż zmuszać małoletniego do niechcianych kontaktów. 


\section{Kontakt a relacja z dzieckiem w duchu odpowiedzialności rodzicielskiej}

Na rodzicach spoczywa ogromna odpowiedzialność za dziecko, jego prawidłowy rozwój i wychowanie. Odpowiedzialność ta winna być istotą relacji rodzice-dzieci i nie może być utożsamiana z władzą rodzicielską, której zakres i zasady określa art. 95 k.r.io. Odpowiedzialność rodzicielska, rozumiana jako „zadanie, postawa i relacje rodziców z dzieckiem z poszanowaniem jego godności i praw, zgodnie z porządkiem społeczno-prawnym" (Kodeks rodzinny. Projekt, 2019, s. 428), stała się fundamentem projektu nowego Kodeksu rodzinnego, opracowanego przez Komisję Kodyfikacyjną Prawa Rodzinnego, powołaną przez Rzecznika Praw Dziecka, której obradom przewodniczył prof. S.L. Stadniczeńko. Kategoria władzy rodzicielskiej, która dominuje w obecnie obowiązujących przepisach prawa polskiego, stwarza niebezpieczeństwo implikacji postrzegania dziecka jako „poddanego” władzy rodzicielskiej, a rodziców jako uzurpatorów tej władzy (więcej: Michalak i Jaros, 2014, s. 37). Odpowiedzialność rodzicielska jest kategorią szerszą od władzy rodzicielskiej, pozwala bowiem sięgnąc do norm społecznych, kulturowych, religijnych i prawnych związanych z praktyką wychowawczą. B. Smolińska-Theiss podkreśla, że:

\footnotetext{
Odpowiedzialność rodzicielska jest kategorią etyczną i społeczną, opisującą zobowiązana rodzica wobec dziecka i społeczeństwa. Ma wymiar indywidualny i społeczny. Jest odpowiedzialnością za dziecko, wobec dziecka, przed dzieckiem, a także wobec rodziny bliższej i dalszej, wobec wspólnoty lokalnej, wobec społeczeństwa, historii czy Boga. (...) Otwiera się na wartości, rodzicielskie plany, oczekiwania wobec siebie i dziecka, także na obowiązujące normy społeczne i prawne (Smolińska-Theiss, 2020, s. 246).
}

Odpowiedzialność rodzicielska to między innymi relacja rodziców z dzieckiem z poszanowaniem jego godności i praw, zgodnie z porządkiem społeczno-prawnym. Złożone relacje między członkami rodziny tworzą sytuacje wychowawcze, wyposażają w „podstawowe sensy istotowe dla dalszego życia w społeczeństwie poza wspólnotą rodzinną (...). Dziecko znajduje się zawsze w koniecznej relacji do rodziny, jeśli nie naturalnej, to zastępczej. Konieczność ta wpisana jest w naturę i obiektywny układ inklinacji i struktur" (Stadniczeńko, 2019, s. 39-40). Z kolei sytuacja wychowawcza to „szczególne spotkanie dwóch osób" w miejscu, w którym się działa, wychowuje, koncentruje na realizowaniu określonych wartości, na tym, co być powinno, co umiejscowione w przyszłości (Ablewicz, 1998). Sytuacje wychowawcze mogą być zarówno pozytywne, jak i negatywne w przypadku tych drugich należy zweryfikować relację, która stała się źródłem złej sytuacji wychowawczej.

Po rozstaniu rodziców ich relacja $z$ dzieckiem nabiera nowego wymiaru. Wydaje się, że normatywna kategoria „kontaktu z dzieckiem” stanowi pojęcie nieadekwatne do tego, co winno się dziać pomiędzy dzieckiem a rodzicem w sytuacji kryzysu, jakim niewątpliwie jest rozpad rodziny. W duchu odpowiedzialności rodzicielskiej zdecydowanie bardziej właściwe byłoby używanie pojęcia utrzymywania relacji osobistych dziecka 


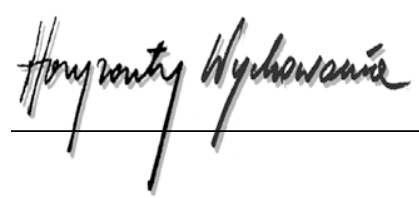

z rodzicem. Kontakt z dzieckiem stanowi raczej zabezpieczenie formalno-prawne stosunków w rodzinie mających miejsce po rozstaniu rodziców. Każdy kontakt niesie za sobą tworzenie określonych relacji, które stanowią sytuacje wychowawcze dla dziecka. To rodzic - w poczuciu odpowiedzialności - winien określić, czy sytuacja wychowawcza, którą wytwarza, jest dobra dla dziecka czy też nie. Bezduszne respektowanie prawa do kontaktu z dzieckiem może tworzyć patologiczną relację rodzic-dziecko i nieść negatywne konsekwencje wychowawcze.

\section{Międzynarodowe regulacje dotyczące kontaktu/relacji z rodzicem}

W systemie uniwersalnym podstawowym aktem prawnym regulującym sytuację prawną dziecka jest Konwencja o prawach dziecka przyjęta przez Zgromadzenie Ogólne Narodów Zjednoczonych z dnia 20 listopada 1989 r., ratyfikowana przez Rzeczpospolitą Polską w dniu 7 czerwca 1991 r. (Dz.U. z 1991 r., Nr 120, poz. 526). W art. 8 ust. 1 Konwencja proklamuje prawo dziecka do zachowania tożsamości, w tym obywatelstwa, nazwiska, stosunków rodzinnych. Ponadto w art. 9 ust. 3 wskazano, że: „Państwa - Strony będą szanowały prawo dziecka odseparowanego od jednego lub obojga rodziców do utrzymywania regularnych stosunków osobistych i bezpośrednich kontaktów z obojgiem rodziców, z wyjątkiem przypadków, gdy jest to sprzeczne z najlepiej pojętym interesem dziecka". Art. 10 ust. 2 Konwencji stanowi natomiast o prawie dziecka do utrzymywania regularnych, osobistych stosunków i bezpośrednich kontaktów z rodzicami przebywającymi w różnych państwach z wyjątkiem okoliczności nadzwyczajnych. Konwencja o prawach dziecka wyróżnia dwie kategorie praw dziecka odseparowanego od rodzica - a mianowicie prawo do regularnych stosunków osobistych oraz do bezpośrednich kontaktów, przy czym jako pierwsze wymienione zostały stosunki osobiste, co potwierdza, że istnieje kategoria szersza i istotniejsza niż kontakt z dzieckiem odseparowanym. W ujęciu odpowiedzialności rodzicielskiej jest to relacja osobista stwarzająca sytuację wychowawczą.

Istotne jest także zwrócenie uwagi, że Konwencja o prawach dziecka określa, że prawo do stosunków i kontaktów jest prawem dziecka. Zgodnie z postanowieniami Konwencji rodzic ma prawo (a jednocześnie i w pierwszej kolejności odpowiedzialność) oraz obowiązek do zapewnienia dziecku możliwości ukierunkowania go i udzielenia mu rad przy korzystaniu z praw dziecka wynikających z kart Konwencji (art. 5). Implikacją prawa dziecka do relacji z rodzicem oraz odpowiedzialności rodzica i jego prawa do ukierunkowania i doradzania dziecku jest prawo rodzica do relacji z dzieckiem. Jednak w takim układzie powinno być ono odczytywane jako realizacja prawa dziecka, nie zaś jako prawo sprzężone z obowiązkiem dziecka do kontaktowania się z rodzicem na wzór stosunku zobowiązaniowego.

Prawo do utrzymywania relacji z rodzicem żyjącym w rozłączeniu zostało wyartykułowane również w systemie regionalnym Rady Europy. Konwencja o ochronie praw człowieka i podstawowych wolności z 4 listopada 1950 r., ratyfikowana przez Polskę 19 stycznia 1993 r. (Dz.U. 1993, Nr 61, poz. 284 ze zm.) w art. 8 stanowi prawo do 
poszanowania życia prywatnego i rodzinnego. Na podstawie tego artykułu Europejski Trybunał Praw Człowieka wypracował standardy, według których kontakt z dzieckiem powinien być dostępny dla obojga rodziców zarówno w trakcie trwania ich związku, jak i po jego rozstaniu (Czepek, 2016). Trybunał podkreśla, że decyzja o przyznaniu kontaktu z małoletnim ma być podejmowana z uwzględnieniem najlepszego interesu dziecka i jego dobra (więcej: Holewińska-Łapińska i in., 2016, s. 7 i n.).

Ważnym aktem w systemie Rady Europy jest Konwencja z dnia 15 maja 2003 r. o kontaktach z dzieckiem (ratyfikowana ustawą z dnia 23 kwietnia 2009 r. o ratyfikacji Konwencji w sprawie kontaktów z dziećmi, sporządzonej w Strasburgu w dniu 15 maja 2003 r., Dz.U. Nr 68, poz. 576 - dalej: Konwencja o kontaktach). Kontakt z dzieckiem w rozumieniu Konwencji to: pobyt dziecka przez określony czas albo jego spotkanie z członkiem rodziny, z którym dziecko stale nie mieszka, a także każda forma komunikacji między dzieckiem i taką osobą oraz dostarczanie takiej osobie informacji o dziecku albo dziecku o tej osobie (art. 2 a Konwencji). Definicja kontaktu dla celów Konwencji o kontaktach została ujęta szeroko, gdyż obejmuje poza formą komunikacji bezpośredniej i pośredniej, także prawo do regularnego uzyskiwania informacji o sobie.

Co istotne - Konwencja o kontaktach w art. 4 stanowi, że dziecko i rodzice (w takiej kolejności) mają prawo uzyskania i utrzymywania ze sobą regularnych kontaktów, a ograniczenie lub wykluczenie takich kontaktów możliwe jest tylko wtedy, gdy jest to niezbędne dla dobra dziecka. A zatem kontakty z dzieckiem nie są ujmowane w kategorii obowiązku dziecka czy też rodzica, lecz w kategorii uprawnienia. Konwencja przypisuje przy tym pierwszeństwo utrzymywania nienadzorowanego kontaktu dziecka z rodzicem, a w sytuacji gdy nie jest to zgodne z dobrem dziecka, „należy rozważyć możliwość zastosowania nadzorowanego kontaktu osobistego lub innych form kontaktu z tym rodzicem" (tak art. 4 ust. 3 Konwencji o kontaktach). W Konwencji o kontaktach znalazły się także proceduralne wytyczne dla organów sądowych. Niezwykle interesujące jest zobowiązanie sądu do zapewnienia świadomości rodziców na temat tego, jak istotne znaczenie mają regularne kontakty z dzieckiem (art. 7).

Przyjęcie koncepcji relacji osobistej z dzieckiem, budującej sytuację wychowawczą w duchu odpowiedzialności rodzicielskiej, mogłoby zmienić optykę analizowania spraw o uregulowanie kontaktów (w tym również wśród sędziów) i ułatwić proces uświadamiania rodziców co do znaczenia relacyjności stosunku z dzieckiem.

Obecnie w ramach Rady Europy podejmowane są kroki w celu zapewnienia najszerszej ochrony dziecku, którego rodzice żyją w rozłączeniu. W 2019 r. Komitet Ministrów Rady Europy powołał na lata 2020-2021 specjalny Komitet Ekspertów do spraw zabezpieczenia najlepszego interesu dziecka w przypadku rodziców żyjących w rozłączeniu i w sprawach opiekuńczych (Extract from CM(2019)131). W grudniu 2020 r. Komitet przedstawił wyniki dotychczasowej analizy i wskazał na trzy zasady przewodnie, których należy bezwzględnie przestrzegać w przypadku separacji rodziców (CJ/ENF-ISE(2020)7A). Są to:

1. dobro dziecka - które ma być uwzględnione we wszystkich decyzjach dotyczących dziecka w szczególności w trudnej chwili rozstania rodziców; 


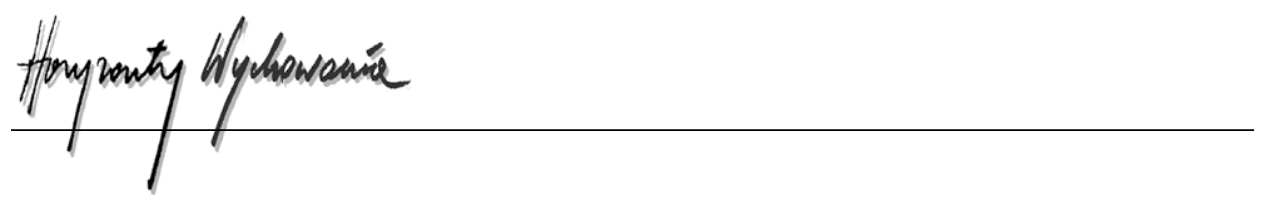

2. odpowiedzialność rodzicielska - zgodnie z którą to rodzice ponoszą wspólną i równą odpowiedzialność za dziecko, a ich rozstanie nie może wpływać na prawo dziecka do utrzymywania osobistych relacji z obojgiem rodziców, chyba że w najlepszym interesie dziecka leży inne rozwiązanie;

3. wysłuchanie dziecka - zarówno w postępowaniu sądowym, jak i w postępowaniach polubownych.

Komitet Ekspertów Rady Europy, opracowujący podstawowe standardy w sprawach rodzinnych, kładzie nacisk na te same dokładnie zasady, które przyświecały Komisji Kodyfikacyjnej Prawa Rodzinnego, powołanej przez Rzecznika Praw Dziecka, skutkującej projektem Kodeksu rodzinnego z dnia 12 lipca 2018 r. (Kodeks rodzinny. Projekt, 2019, s. 423 i n.). Na podkreślenie zasługuje ujęcie prawa do relacji z rodzicem, które według Komitetu Ekspertów wynika z odpowiedzialności rodzicielskiej. Podobnie jak w Konwencji o prawach dziecka wyróżnione zostały dwie kategorie praw dziecka odseparowanego od rodzica, w pierwszej kolejności wskazując na prawo do osobistych relacji. A zatem sam kontakt jest zbyt wąską kategorią stosunków między rodzicami i dziećmi.

Biorąc pod uwagę systemy regionalne, o kontaktach z dzieckiem traktuje także Karta praw podstawowych Unii Europejskiej (Dz. Urz. UE 2016 C, Nr 202, s. 1). Art. 24 ust. 3 Karty praw podstawowych stanowi: „Każde dziecko ma prawo do utrzymywania stałego, osobistego związku i bezpośredniego kontaktu z obojgiem rodziców, chyba że jest to sprzeczne z jego interesami”. W oficjalnym tłumaczeniu na język polski Karty praw podstawowych użyto pojęcia prawo do „osobistego związku”, natomiast w angielskiej wersji językowej Karty mowa o „personal relationship”, dla którego lepszym odniesieniem byłby zwrot „relacja osobista” niż „osobisty związek”. A zatem również w strukturach unijnych stosunki dziecka z rodzicami żyjącymi w rozłączeniu nie są sprowadzane li tylko do prawa kontaktowania się, ale przede wszystkich do pozostania w stałych relacjach osobistych pomimo kryzysu w rodzinie.

Żaden z międzynarodowych instrumentów gwarantujących prawo do utrzymywania kontaktów, czy też szerzej - relacji dzieci z rodzicami po ich rozstaniu, nie traktuje sytuacji dziecka w kategorii obowiązku kontaktowania się z rodzicem, jak czyni to obecnie obowiązujący w Polsce k.r.io. Jest to moim zdaniem kolejny argument wykazujący, że regulacja art. $113 \S 1$ k.r.io. jest wadliwa i może stanowić podstawę interpretacji przedkładającej interes rodzica nad interes dziecka.

\section{Podsumowanie, postulaty de lege ferenda}

Analiza sytuacji dziecka w relacji osobistej z rodzicem w kontekście rozstania rodziców ukazała niedostatki polskiej regulacji w tym zakresie. Aktualnie obowiązujące przepisy ujmują w ramy prawne zbyt wąską kategorię zachodzących między rodzicami i dziećmi stosunków, jakimi są kontakty, a przy tym regulacja kodeksowa może prowadzić do interpretacji uwzględniania interesu rodzica przed interesem dziecka w sprawach o uregulowanie kontaktów. 
Nakładanie na dziecko obowiązku utrzymywania relacji z rodzicem po rozpadzie rodziny jest sprzeczne z dobrem dziecka, podważa celowość wysłuchiwania małoletniego w tego typu sprawach (skoro istnieje formalny obowiązek - to na cóż się zda rozsądne życzenie dziecka), jest sprzeczne z uznaniem podmiotowości dziecka i prowadzi do wzmocnienia legalistycznej postawy rodzicielskiej. Tezę tę potwierdza analiza norm międzynarodowych, z których żadna nie ujmuje relacji osobistej dziecka z rodzicem żyjącym w rozłączeniu w kategorii obowiązku dziecka. Osobista relacja dziecka z rodzicem jest przede wszystkim prawem dziecka. Stanowi także prawo rodzica, jednak jest ono ściśle powiązane z prawem dziecka do relacji i obowiązkiem rodzica stwarzania sytuacji wychowawczych poprzez budowanie relacji i przekazywanie wzorców zachowania. Uznaję pierwszeństwo prawa dziecka do rodziców przed ochroną praw rodzicielskich, akcentując podmiotowość dziecka jako osoby. W związku z tym postuluję zmianę treści art. 113 k.r.io., polegającą na wykreśleniu obowiązku dziecka do realizowania kontaktów z rodzicami.

Ponadto ujęcie prawa do kontaktu zbyt wąsko określa sytuacje mające miejsce między dzieckiem i rodzicem po rozstaniu rodziców. Pełniejsze urzeczywistnianie zasady dobra dziecka w poczuciu odpowiedzialności rodzicielskiej będzie możliwe przy przyjęciu prawa dziecka do utrzymywania relacji osobistych z rodzicem z jednoczesnym obowiązkiem i prawem rodzica do relacji osobistych z dzieckiem. Relacja osobista łączy się z interakcją, dialogiem, współpracą, wymianą doświadczeń, umożliwia zdobywanie wiedzy i umiejętności. Z kolei kontakt nastawiony jest na fizyczny aspekt przebywania ze sobą, niekoniecznie związany z dwustronną komunikacją, budowaniem relacji i wychowywaniem.

\section{BIBLIOGRAFIA}

Ablewicz, K. (1988). Sytuacja wychowawcza jako szczególne spotkanie dwóch osób - szkic problematyki. Zeszyty Naukowe Uniwersytetu Jagiellońskiego. Prace Pedagogiczne, 8.

Ciepła, H. (2010). Nowelizacje kodeksu rodzinnego i opiekuńczego z komentarzem. Warszawa: LexisNexis.

CJ/ENF-ISE(2020)7A. (2020). Analysis of international and European standards and practical tools, identification of gaps and possible proposals. https://rm.coe.int/ cj-enf-ise-2020-7a-analysis-of-international-and-european-standards-an/1680a0a962

Czepek, J. (2016). Prawo do kontaktu obojga rodziców z dzieckiem. LEX/el. https://sip.lex.pl/komentarze-i-publikacje/linie-orzecznicze/prawo-do-kontaktu-obojga -rodzicow-z-dzieckiem-419726017

Długoszewska, J. (2012). Przesłanki oraz skutki ograniczenia i pozbawienia władzy rodzicielskiej. Warszawa: LexisNexis.

Extract from CM(2019)131. (2019). Committee of Experts on the Rightsand the Best Interests of the Child in Parental Separation in Care Proceedings. https://rm.coe.int/ cj-enf-ise-2020-2021-en/1680992cb5

Haak, H. (2017). Postępowanie w sprawach dotyczących kontaktów z dzieckiem - wybrane zagadnienia. W: J. Jeżewski i A. Pawlak (red.), Człowiek. Prawo. Państwo. Księga Jubileuszowa dedykowana Stanisławowi Leszkowi Stadniczeńko (s. 399-416). Warszawa: Wyższa Szkoła Finansów i Zarządzania w Warszawie.

Hendrych, K. (2016). Wykonywanie władzy rodzicielskiej i kontaktów w warunkach istnienia elementu zagranicznego. Warszawa: Biuro Rzecznika Praw Dziecka. 


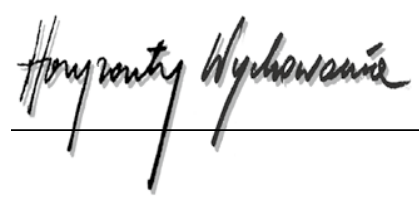

Holewińska-Łapińska, E., Domański, M. i Słyk, J. (2016). Orzecznictwo w sprawach o wykonanie kontaktów z dziećmi. Prawo w Działaniu. Sprawy Cywilne, 25, 7-37.

Ignaszewski, J. (2011). Komentarz do spraw o kontakty z dzieckiem. Warszawa: Wolters Kluwer Polska.

Justyński, T. (2011). Prawo do kontaktów z dzieckiem w prawie polskim i obcym. Warszawa: Wolters Kluwer Polska.

Karta praw podstawowych Unii Europejskiej. Dz. Urz. UE 2016 C, Nr 202, s. 1.

Konstytucja Rzeczypospolitej Polskiej z dnia 2 kwietnia 1997 r. Dz.U. 1997, Nr 78, poz. 483 ze zm.

Konwencja o ochronie praw człowieka i podstawowych wolności z dnia 4 listopada 1950 r. Dz.U. 1993, Nr 61, poz. 284 ze zm.

Konwencja o prawach dziecka przyjęta przez Zgromadzenie Ogólne Narodów Zjednoczonych z dnia 20 listopada 1989 r. Dz.U. z 1991 r., Nr 120, poz. 526.

Konwencja z dnia 15 maja 2003 r. o kontaktach z dzieckiem. Dz.U. Nr 68, poz. 576.

Michalak, M. i Jaros, P. (2014). Prawo dziecka do obojga rodziców. Dziecko Krzywdzone. Teoria, Badania, Praktyka, 13(3), 11-55.

Okoń, W. (1996). Nowy słownik pedagogiczny. Warszawa: Wydawnictwo Akademickie „Żak”.

Plopa, M. (2008). Psychologia rodziny. Teoria i badania. Kraków: Impuls.

Kodeks rodzinny. Projekt. (2019). W: S.L. Stadniczeńko i M. Michalak (red.), O potrzebie nowego Kodeksu rodzinnego i jego podstawach aksjologicznych. W 30. rocznicę uchwalenia Konwencji o prawach dziecka. Toruń: Wydawnictwo Adam Marszałek.

Smolińska-Theiss, W. (2020). Władza rodzicielska vs odpowiedzialność rodzicielska - pedagogiczny kontekst Kodeksu rodzinnego i opiekuńczego. W: A. Pawlak, B. Skwarek i J. Stadniczeńko (red.), W trosce o rozwój i bezpieczeństwo dziecka - aspekty społeczno-prawne (s. 235-249). Warszawa: Akademia Ekonomiczno-Humanistyczna.

Sokołowski, T. (2013). W: H. Dolecki i T. Sokołowski (red.), Kodeks rodzinny i opiekuńczy (wyd. 2). Warszawa: Lex a Wolters Kluwer business.

Stadniczeńko, S.L. (2019). Podstawy aksjologiczne i intelektualne kształtowania projektu Kodeksu rodzinnego. W: S.L. Stadniczeńko i M. Michalak (red.). O potrzebie nowego Kodeksu rodzinnego i jego podstawach aksjologicznych. W30. rocznicę uchwalenia Konwencji o prawach dziecka. Toruń: Wydawnictwo Adam Marszałek.

Stadniczeńko, S.L. (2015). Prawo dziecka do wychowania w rodzinie. W: S.L. Stadniczeńko (red.), Konwencja o prawach dziecka. Wybór zagadnień (artykuły i komentarze). Warszawa: Biuro Rzecznika Praw Dziecka.

Stojanowska, W. (2000). Władza rodzicielska pozamałżeńskiego i rozwiedzionego ojca. Studium socjologiczno-prawne. Warszawa: Wydawnictwo Akademii Pedagogiki Specjalnej.

Stojanowska, W. (2011). W: W. Stojanowska (red.), Nowelizacja prawa rodzinnego na podstawie ustaw z 6 listopada 2008 r. i 10 czerwca 2010. Analiza. Wykładnia. Komentarz. Warszawa: LexisNexis.

Ustawa z dnia 17 listopada 1964 r. Kodeks postępowania cywilnego. Dz.U. 2020, poz. 1575 ze zm. (t.j.). Ustawa z dnia 25 lutego 1964 r. Kodeks rodzinny i opiekuńczy. Dz.U. z 2020, poz. 1359 ze zm. (t.j.). Zajączkowska, J. (2018). Aspekty prawne kontaktów z dzieckiem. Ruch Prawniczy, Ekonomiczny i Socjologiczny, 80(1), 269-285.

\section{Copyright and License}

This article is published under the terms of the Creative Commons Attribution - NoDerivs (CC BY- ND 4.0) License http://creativecommons.org/licenses/by-nd/4.0/ 